Sikirynska D. O., Hudyma A. A., Shulhai A. H., Pokhodun K. A. The effect of cranioskeletal trauma complicated by blood loss on the functional state of the liver in the early period of traumatic disease in rats with different resistance to hypoxia and their correction. Journal of Education, Health and Sport. 2021;11(2):256-269. eISSN 2391-8306. DOI http://dx.doi.org/10.12775/JEHS.2021.11.02.025

https://apcz.umk.pl/czasopisma/index.php/JEHS/article/view/JEHS.2021.11.02.025

https://zenodo.org/record/5122912

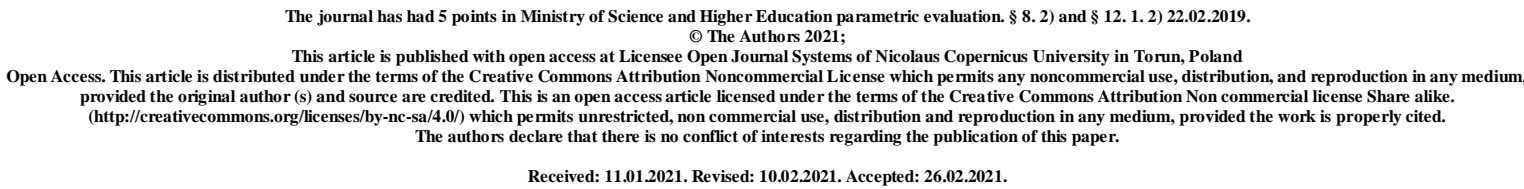

UDK 616.711/.714-001.3-005.1-036.4:616.36-008.1]-092.9

\title{
THE EFFECT OF CRANIOSKELETAL TRAUMA COMPLICATED BY BLOOD LOSS ON THE FUNCTIONAL STATE OF THE LIVER IN THE EARLY PERIOD OF TRAUMATIC DISEASE IN RATS WITH DIFFERENT RESISTANCE TO HYPOXIA AND THEIR CORRECTION
}

\author{
D. O. Sikirynska, A. A. Hudyma, A. H. Shulhai, K. A. Pokhodun
}

\section{Ivan Horbachevsky Ternopil National Medical University of the Ministry of Health of Ukraine}

Abstract

Introduction. Traumatic events are considered to be one of the current problems in modern urban society. Beyond being the immediate cause of the death of the injured, the development of multiple organ failure syndrome is a perilous complication of severe multiple and combined trauma. An experimental cranioskeletal trauma is known to be accompanied by internal organ dysfunction. Nonetheless, the development of organ dysfunction in terms of hypoxia resistance in the presence of cranioskeletal trauma remains insufficiently studied.

The objective of research: to establish the dynamics of the functional state of the liver in the presence of cranioskeletal trauma, complicated by blood loss in rats with different hypoxia resistance in the early period of traumatic disease and evaluate the efficacy of Thiocetam in the correction of identified abnormalities. 
Material and methods: The experimental studies were conducted on 196 white nonlinear male rats weighing 180-200g. Initially, an individual resistance to hypoxia of the rats was estimated, and the animals demonstrated high- and low- resistance value to hypoxia (HR and LR, respectively) were selected for the further study. The HR- and LR-rats were separately divided into 4 groups: control and three experimental once. In the first experimental groups the HR-and LR-animals were induced the cranioskeletal trauma under thiopental sodium anesthesia $\left(40 \mathrm{mg} \cdot \mathrm{kg}^{-1}\right)$; the animals of the second experimental groups were inflicted the acute blood loss of $20-22 \%$ of circulating blood volume; in the third experimental groups, the HR and LR animals were subjected to an acute blood loss following the cranioskeletal trauma and administered the intraperitoneal injection of the Thiocetam at a dose of $250 \mathrm{mg} \cdot \mathrm{Kg}^{-1}$ of body weight once a day for correction. The bile excretion function of the liver was analyzed in the controls and experimental groups of animals 1, 3 and 7 days after trauma.

The results and discussion. The conducted studies indicated the higher rate of bile excretion in the control group of LR-rats compared to the control of HR-rats. The rate of bile excretion was occurred decreased in both HR- and LR-rats under the influence of the cranioskeletal trauma. However, the degree of decrease in the studied parameter of the LRrats was considerably greater than the corresponding value of the HR-rats. An additional blood loss model resulted in more marked abnormalities, particularly in the experimental group of LR-rats. The 7-day administration of Thiocetam led to the significant decrease in the abnormal bile excretion rate in the experimental groups of HR- and LR-rats compared to the animals without corrective medication. The analysis of deviation degree of the studied parameter in the animals administered Thiocetam in relation to the animals without correction evidenced better efficacy of the medication in the experimental group consisted of LR-rats compared to the group of HR-rats, especially under the conditions of additional acute blood loss model. Consequently, Thiocetam is able to compensate less-developed defense mechanisms of LR-rats compared to the HR-rats, which should be taken into consideration in real-life clinical practice settings in the comprehensive treatment of the injured with cranioskeletal trauma complicated by blood loss considering the possibility to determine their resistance to hypoxia.

Conclusions. The rate of bile excretion as a basic indicator of the functional state of the liver in the intact LR-rats is found to be substantially higher than in HR-rats. The degree of decrease in the rate of bile excretion is significantly greater in LR-rats after 7 days of the post-traumatic period under the influence of cranioskeletal trauma complicated by acute blood 
loss. The administration of Thiocetam is accompanied by a marked positive effect on the rate of bile excretion in the HR- and LR-rats, but the degree of increase in the studied parameter is considerably greater in the experimental group of LR-rats.

Key words: cranioskeletal trauma; blood loss; hypoxia resistance; bile excretion rate; thiocetam.

Introduction. Traumatic events are considered to be one of the current problems in modern urban society. In recent years, its structure is predominated by high kinetic injuries, which lead to severe multiple and combined trauma. Furthermore, there is an improvement in the provision of emergency medical services to the trauma-affected patients in both prehospital and early hospital phases, which has substantially decreased the mortality risk of the injured in the acute period of traumatic disease. However, a successful shock resuscitation of the trauma patients does not guarantee the patient's survival. It is associated with the development of multiple organ failure syndrome, which is the immediate cause of the death of the injured. All of the above require the objective need for an in-depth study on the pathogenesis of the traumatic disease and establishing the pathogenetically justified corrective measures $[5,15]$.

One of the key mechanisms of organ and system dysfunction under conditions of traumatic disease is the enhancement of lipid peroxidation with the co-presence of systemic membranopathy and loss of membrane-dependent functions [8, 13].

To date, it has been established that, as a consequence of these mechanisms, an experimental cranioskeletal trauma is accompanied by internal organ dysfunction, particularly the liver [6], kidneys [10], and small intestine [10]. Nonetheless, the development of organ dysfunction in terms of hypoxia resistance in the presence of cranioskeletal trauma, taking into account that the pro-oxidant/antioxidant balance [2] is the basis of hypoxia resistance and the disturbance of which is the starting point of organ lesions remote from the site of the initial trauma, remains insufficiently studied.

The objective of research: to establish the dynamics of the functional state of the liver in the presence of cranioskeletal trauma, complicated by blood loss in rats with different hypoxia resistance in the early period of traumatic disease and evaluate the efficacy of Thiocetam in the correction of identified abnormalities.

Material and methods: The experimental studies were conducted on 196 white nonlinear male rats weighing 180-200g, which were housed in standard vivarium conditions. Initially, according to the method described in [14], the individual resistance to hypoxia of the 
rats was estimated, and the animals were classified into two groups based on the above criteria: rats that demonstrated high- and low resistance to hypoxia (HR and LR, respectively). In 14 days, the HR- and LR-rats were separately divided into 4 groups: control (each contained 6 intact rats differently resistant to hypoxia), and three experimental once. In the first experimental groups of HR-and LR-animals (36 animals), the rats were subjected to a simulated cranioskeletal trauma through a sequential measured strike to the skull with subsequent receiving of moderately severe closed craniocerebral injury and measured blow to the femur resulted in a closed femoral fracture under thiopental sodium anesthesia $\left(40 \mathrm{mg} \cdot \mathrm{kg}^{-}\right.$ ${ }^{1}$ ) [1]. The HR- and LR-animals of the second experimental groups (36 rats) were inflicted the additional acute blood loss model of $20-22 \%$ of circulating blood volume by severing a femoral vein under aseptic and antiseptic conditions [16]. In the third experimental groups, the HR- and LR-rats (24 animals) administered the intraperitoneal injection of the Thiocetam (JSC «Halychpharm», Lviv, Ukraine) at a dose of $250 \mathrm{mg} \cdot \mathrm{Kg}^{-1}$ of body weight once a day for correction following the cranioskeletal trauma complicated by acute blood loss [12].

The bile excretion function of the liver was analyzed in the experimental groups of animals 1, 3 and 7 days after trauma, which corresponded to the acute period and the period of early manifestations of traumatic disease. The common bile duct was catheterized and the bile samples were collected from animals within an hour under thiopental sodium anesthesia $\left(60 \mathrm{mg} \cdot \mathrm{kg}^{-1}\right)$. The rate of bile excretion calculated per 1 hour as well as the weight of animal was determined based on the above data. The animals of control groups solely administered thiopental sodium anesthesia and the bile excretion rate was analyzed after 1 day.

In order to neutralize the impact on different values of bile excretion rates, the ratio of individual values of bile excretion rates in the experimental groups to the mean value of control group was calculated in addition to the determination of the absolute values of the studied parameter in both control groups. Based on the above data, the statistical significance of the deviation degree of the studied parameter in the experimental groups of HR-and LRrats under conditions of the traumas was analyzed. Moreover, the average ratio of individual values of bile excretion rates of animals administered corrective medication to the mean value of groups without correction was determined in order to indicate the statistical significance of the deviation degree of the studied parameter in animals administered Thiocetam compared to the animals without corrective medication.

All experimental procedures fulfilled the international standards for the humane treatment of animals in compliance with the regulations of «The European Convention for the protection of vertebrate animals used for experimental and other scientific purposes 
(European Convention, 1986)». The test animals were subsequently euthanized after bile collection through complete exsanguination from the heart.

All obtained data were processed to the statistical analysis by the nonparametric The Mann-Whitney U test using STATISTICA 10.0 software («StatSoft Inc.», USA).

The results and discussion. As can be seen from Table 1, the rate of bile excretion in the control group of HR-rats was observed as statistically significant lower than the corresponding value in the control group comprised of LR-rats (by 17,9\%, p<0,05).

A combined craniocerebral and femur trauma resulted in decrease in the studied parameter in the group of LR-rats after 1, 3 and 7 days by $10,4 \%, 23,5 \%$ and 35,1\%, respectively. The differences were statistically significant, compared with those of the control groups, at all time periods of the post-traumatic period $(\mathrm{p}<0,05)$. There was also a statistically significant decreased parameter in HR-rats than in the control group within the same study period by $11,6 \%, 16,5 \%$ and $24,3 \%$, respectively $(\mathrm{p}<0,05)$. The intergroup comparison of the bile excretion rates indicated a substantially lower absolute of the studied parameter in the HR-rats as compared to the LR-rats after 1 day of the posttraumatic period (by 19,1\%, $\mathrm{p}<0,05)$. After 3 and 7 days, the differences between the comparison groups were nonsignificant $(\mathrm{p}>0,05)$.

The analysis of dynamics of the average ratio of individual values of bile excretion rates to the mean value of control group (Table 2) demonstrated that the differences between the studied groups were statistically non-significant after 1 and 3 days ( $p>0,05)$. Meanwhile, the value of the studied parameter of the group consisted of HR-rats was significantly higher after 7 days (by 16, $9 \%$, p <0, 05).

An additional blood loss model in the background of cranioskeletal trauma also led to a statistically significant decreased bile excretion rate (Table 1) in the LR-rats by 19, 1\%, 34, $3 \%$ and 48, $2 \%$, respectively. The same tendency was observed in the HR-rats, the studied parameter was found statistically significant decreased by 15, 5\%,27, 2\% and 29, $6 \%$, respectively $(\mathrm{p}<0,05)$. The intergroup comparison evidenced a substantially lower bile excretion rate in the HR-rats as compared to the LR-rats after 1 and 3 days of the posttraumaric period (by $14,3 \%$ and $9,1 \%$, respectively, p<0,05). After 7 days, the differences between the comparison groups were non-significant ( $p>0,05)$.

The analysis of dynamics of the average ratio of individual values of bile excretion rates to the mean value of control group (Table 2) indicated statistically non-significant differences between the studied groups $(p>0,05)$ after 1 and 3 days of the experimental period. 
However, the value of the studied parameter of the group consisted of HR-rats was significantly higher after 7 days (by $34,6 \%, p<0,05$ ).

Table 1 - The dynamics of bile excretion rate $\left(\mathrm{ml} \cdot \mathrm{hr}^{-1} \cdot \mathrm{kg}^{-1}\right)$ in response to cranioskeletal trauma complicated by blood loss in rats with different resistance to hypoxia (Me (LQ; UQ)) - median (lower and upper quartiles)

\begin{tabular}{|c|c|c|c|c|}
\hline \multirow{2}{*}{$\begin{array}{l}\text { Hypoxia } \\
\text { resistance }\end{array}$} & \multirow[t]{2}{*}{ Control } & \multicolumn{3}{|c|}{ Time period of posttraumatic period } \\
\hline & & 1 day & 3 days & 7 days \\
\hline \multicolumn{5}{|c|}{ Cranioskeletal trauma } \\
\hline Low-resistant & $\begin{array}{c}2,51 \\
(2,41 ; 2,74) \\
(\mathrm{n}=6)\end{array}$ & $\begin{array}{c}2,25^{*} \\
(2,17 ; 2,31) \\
(n=7)\end{array}$ & $\begin{array}{c}1,92^{* 1 \mathrm{~d}} \\
(1,85 ; 1,95) \\
(\mathrm{n}=7)\end{array}$ & $\begin{array}{c}1,63^{* 1 \mathrm{~d}, 3 \mathrm{~d}} \\
(1,43 ; 1,77) \\
(\mathrm{n}=7)\end{array}$ \\
\hline High-resistant & $\begin{array}{c}2,06^{\#} \\
(1,92 ; 2,14) \\
(\mathrm{n}=6)\end{array}$ & $\begin{array}{c}1,82^{* \#} \\
(1,70 ; 1,97) \\
(\mathrm{n}=8)\end{array}$ & $\begin{array}{c}1,72^{* 1 \mathrm{~d}} \\
(1,58 ; 1,84) \\
(\mathrm{n}=10)\end{array}$ & $\begin{array}{c}1,56^{* 1 \mathrm{~d}, 3 \mathrm{~d}} \\
(1,48 ; 1,75) \\
(\mathrm{n}=10)\end{array}$ \\
\hline \multicolumn{5}{|c|}{ Cranioskeletal trauma + blood loss } \\
\hline Low-resistant & $\begin{array}{c}2,51 \\
(2,41 ; 2,74) \\
(n=6)\end{array}$ & $\begin{array}{c}2,03^{*} \\
(1,96 ; 2,09) \\
(n=6)\end{array}$ & $\begin{array}{c}1,65^{* 1 d} \\
(1,61 ; 1,73) \\
(n=6)\end{array}$ & $\begin{array}{c}1,30^{* 1 \mathrm{~d}, 3 \mathrm{~d}} \\
(1,28 ; 1,39) \\
(\mathrm{n}=5)\end{array}$ \\
\hline High-resistant & $\begin{array}{c}2,06^{\#} \\
(1,92 ; 2,14) \\
(n=6)\end{array}$ & $\begin{array}{c}1,74^{* \#} \\
(1,57 ; 1,87) \\
(\mathrm{n}=8)\end{array}$ & $\begin{array}{c}1,50^{* \# 1 d} \\
(1,38 ; 1,54) \\
(n=9)\end{array}$ & $\begin{array}{c}1,45^{* 1 \mathrm{~d}, 3 \mathrm{~d}} \\
(1,35 ; 1,58) \\
(\mathrm{n}=8)\end{array}$ \\
\hline \multicolumn{2}{|c|}{$\mathrm{p}_{1}$} & $<0,05$ & $<0,05$ & $<0,05$ \\
\hline \multicolumn{2}{|c|}{$\mathrm{p}_{2}$} & $>0,05$ & $<0,05$ & $>0,05$ \\
\hline
\end{tabular}

Notes. Here and in other tables.

1. * - the differences concerning the control group are statistically sighnificant $(\mathrm{p}<0,05)$;

2. \# - the differences between the HR-and LR animals are statistically sighnificant $(p<0,05)$;

3. ${ }^{1 \mathrm{~d}, 3 \mathrm{~d}}$ - the differences concerning 1 day and 3 days of the observation period are statistically sighnificant $(\mathrm{p}<0,05)$;

4. $\mathrm{p}_{1}$ - the probability of differences in the experimental groups of LR-animals with either presense or absence of additional blood loss model;

5. $\mathrm{p}_{2}$ - the probability of differences in the experimental groups of HR-animals with either presense or absence of additional blood loss model.

The intergroup comparison of LR-rats affected by combined craniocerebral and femur trauma depending on either presence or absence of acute blood loss showed that the parameter was statistically significant lower under conditions of blood loss at all time periods of the posttraumatic period compared to the animals without blood loss model (by 9,8\%, 14,1\% and $20,2 \%$, respectively, $\left.\mathrm{p}_{1}<0,05\right)$. The group of HR-rats with cranioskeletal trauma showed the same tendency of decrease in the bile excretion rate in the presence of additional blood loss model, but the outcome was statistically significant after 3 days of the experiment (by 12,8\%, $\left.\mathrm{p}_{2}<0,05\right)$. 
Table 2 - The dynamics of the average ratio of individual values of bile excretion rates to the mean value of control group in response to cranioskeletal trauma complicated by blood loss in rats with different resistance to hypoxia (Me (LQ; UQ)) - median (lower and upper quartiles)

\begin{tabular}{|c|c|c|c|}
\hline \multirow{2}{*}{ Hypoxia resistance } & \multicolumn{3}{|c|}{ Time period of posttraumatic period } \\
\cline { 2 - 4 } & 1 day & 3 days & 7 days \\
\hline \multirow{3}{*}{ Low-resistant } & Cranioskeletal trauma & 0,65 \\
& 0,90 & 0,77 & $(0,57 ; 0,71)$ \\
& $(0,86 ; 0,92)$ & $(0,74 ; 0,78)$ & $(\mathrm{n}=7)$ \\
\hline \multirow{3}{*}{ High-resistant } & $(\mathrm{n}=7)$ & $(\mathrm{n}=7)$ & $0,76^{\#}$ \\
& 0,88 & 0,83 & $(0,72 ; 0,85)$ \\
& $(0,83 ; 0,96)$ & $(0,77 ; 0,89)$ & $(\mathrm{n}=10)$ \\
\hline \multirow{3}{*}{ Low-resistant } & $(\mathrm{n}=8)$ & $(\mathrm{n}=10)$ & 0,52 \\
& Cranioskeletal trauma + blood loss \\
& 0,81 & 0,66 & $(0,51 ; 0,55)$ \\
& $(0,78 ; 0,83)$ & $(0,64 ; 0,69)$ & $(\mathrm{n}=7)$ \\
\hline \multirow{3}{*}{ High-resistant } & $(\mathrm{n}=7)$ & $(\mathrm{n}=7)$ & $0,70^{\#}$ \\
& 0,85 & 0,73 & $(0,66 ; 0,76)$ \\
& $(0,76 ; 0,91)$ & $(0,67 ; 0,75)$ & $(\mathrm{n}=10)$ \\
\hline
\end{tabular}

The administration of corrective medication Thiocetam to the animals affected by combined craniocerebral and thigh trauma (Figure 1) contributed to the increase in bile excretion rate in the LR-rats (by 25, 8\%, p<0, 05) and the HR-rats (by 15, 3\%, p<0, 05) after 7 days of the experiment. The parameter also increased in rats with additional blood loss model under the effect of medication: in the LR-rats group by $39,2 \%(\mathrm{p}<0,05)$ as well as the HR-rats group by $24,1 \%(\mathrm{p}<0,05)$.

The comparison of the average ratio of individual values of bile excretion rates of animals administered corrective medication to the mean value of group without correction (Figure 3) indicated that the degree of increase in bile excretion rate under the administration of Thiocetam did not significantly differ in groups of animals affected by cranioskeletal trauma with different hypoxia resistance $(p>0,05)$, even though there was a tendency to a higher value in the group of LR-rats. However, the parameter was statistically significant higher in the LR-rats as compared to the HR-rats under the additional acute blood loss model (by $15,8 \%, \mathrm{p}<0,05$ ).

The obtained results evidenced the differences in the intensity of bile excretion function of the liver in laboratory white rats that were genetically genetically distinct at hypoxia resistance. 


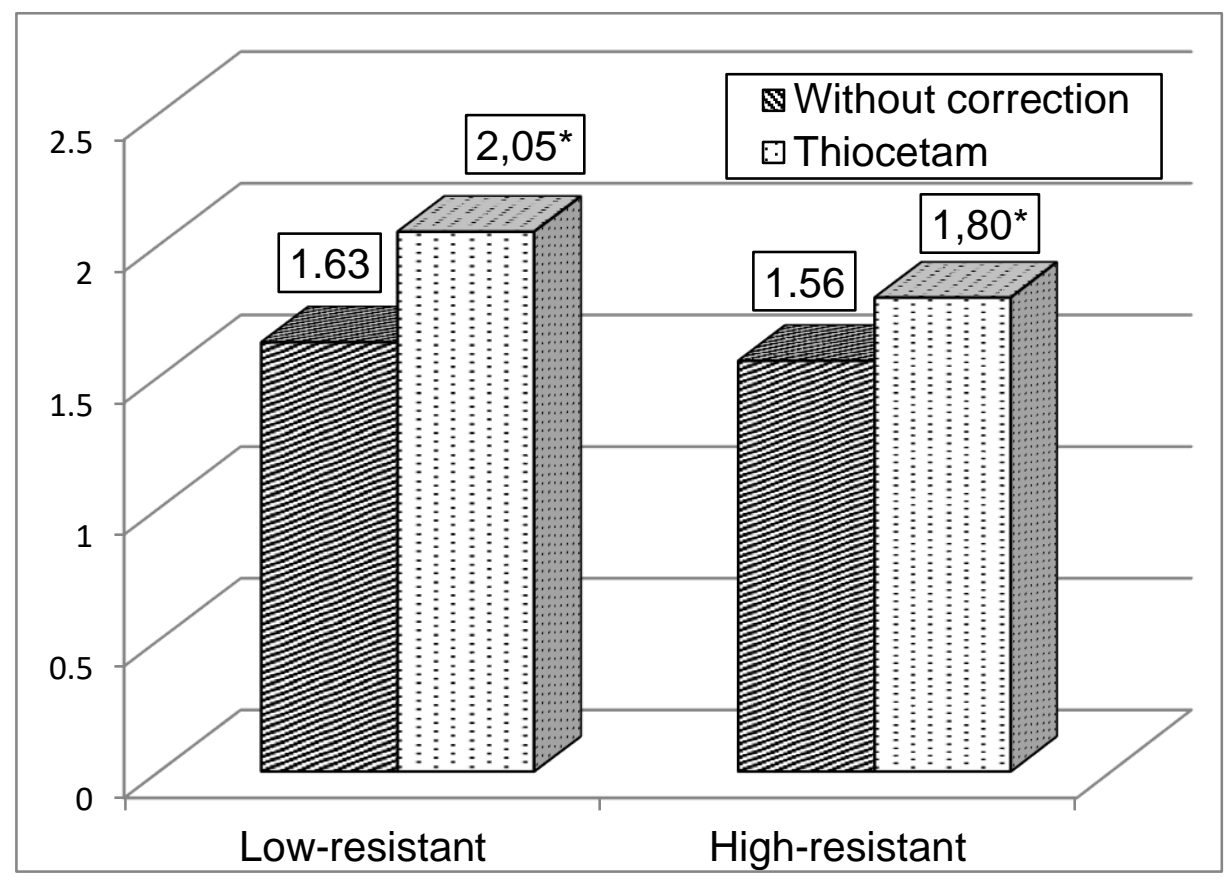

Figure 1 - The effect of Thiocetam on the bile excretion rate $\left(\mathrm{ml} \cdot \mathrm{hr}^{-1} \cdot \mathrm{kg}^{-1}\right)$ after 7 days following the cranioskeletal trauma in rats with different resistance to hypoxia (Here and in Fig. $2:{ }^{*}-$ the differences in relation to animals without corrective medication are statistically significant $\mathrm{p}<0,05)$.

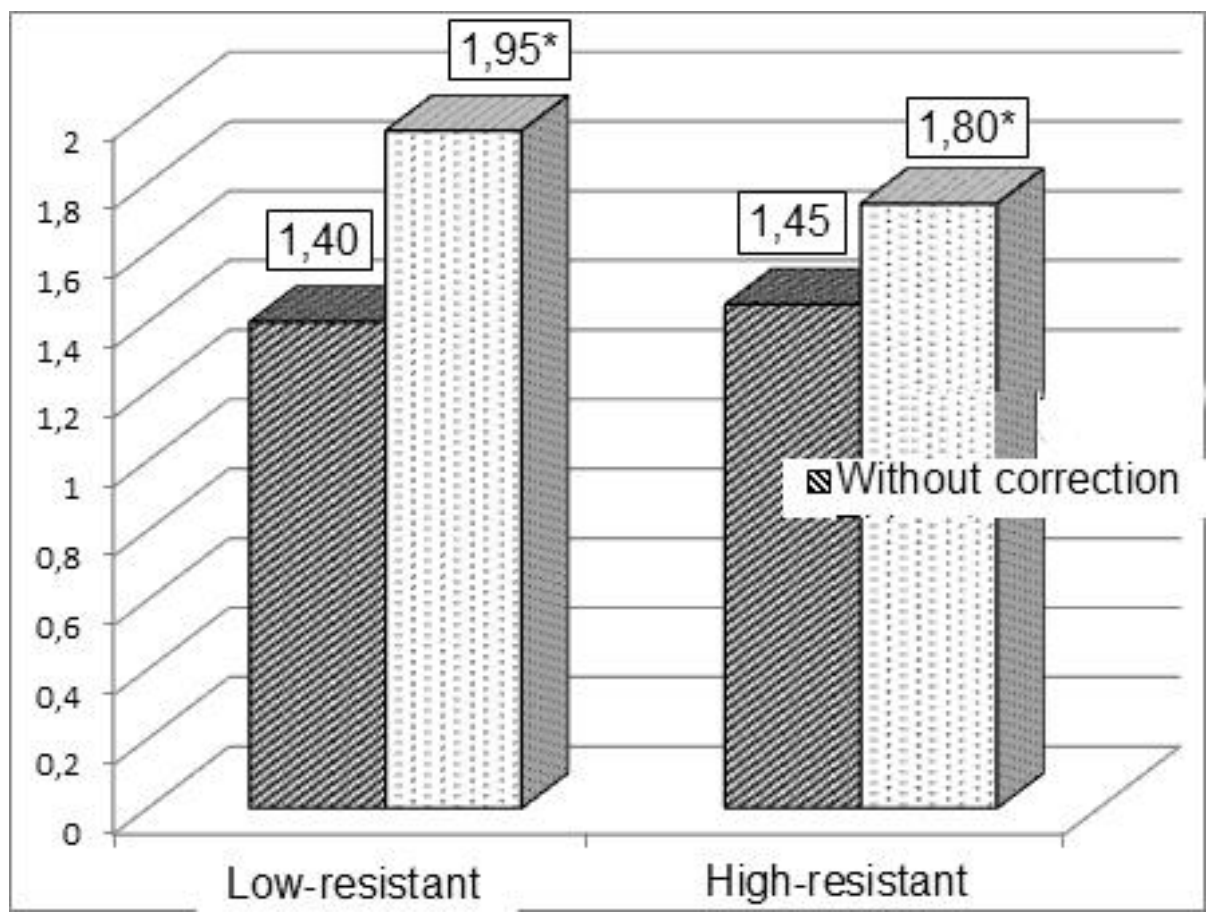

Figure 2 - The effect of Thiocetam on the bile excretion rate $\left(\mathrm{ml} \cdot \mathrm{hr}^{-1} \cdot \mathrm{kg}^{-1}\right)$ after 7 days following the cranioskeletal trauma complicated by blood loss in rats with different resistance to hypoxia 


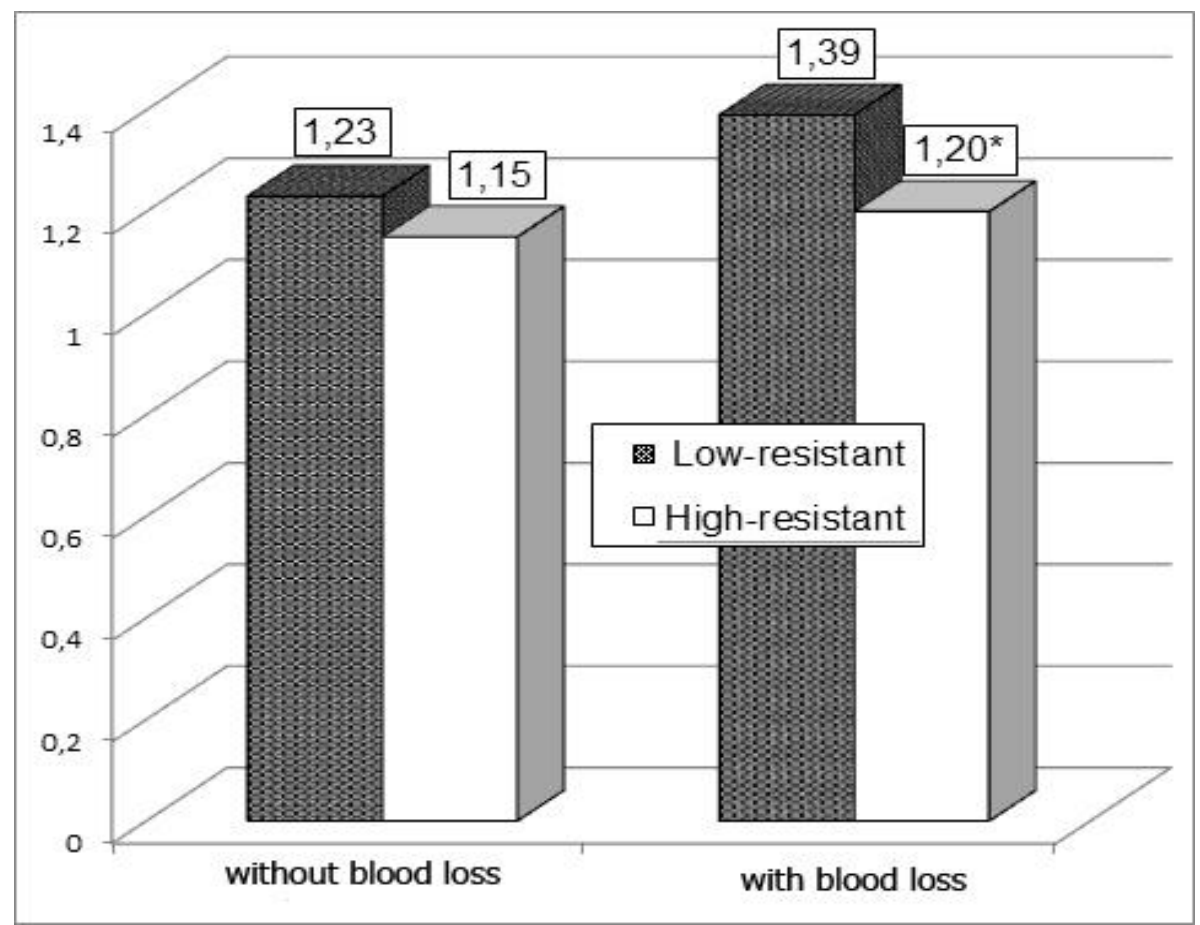

Figure 3 - The dynamics of the average ratio of individual values of bile excretion rates of animals administered corrective medication to the mean value of group without correction under conditions of the cranioskeletal trauma complicated by blood loss in rats with high- and low-resistance to hypoxia.

The rate of bile excretion was higher in the groups of LR-rats. It is established, that the permeability of the biliary pole of hepatocyte plays a fundamental role in the bile excretion process. It can be substantiated that the increased bile excretion rate of LR-rats is mainly associated with the bile fluid excretion.

A cranioskeletal trauma leads to a decrease in the bile excretion rate in both experimental groups of HR-and LR-rats. Probably, this process is to a certain extent related to the impaired production of major constituents of bile, which develops in case of severe trauma, as reported by several authors $[6,8]$. On the other hand, an impaired bile outflow is associated with the reactive inflammatory process in the liver, which is accompanied by a periportal edema and causes a mechanical obstruction of bile flow [7]. Despite the higher initial rate of bile excretion in the LR-rats of control group, the degree of decrease in the studied parameter in this group was considerably greater than the corresponding value of the HR-rats under conditions of a combined craniocerebral and femur trauma, which indicates the higher sensitivity of rats to the pathogenic factors of traumatic disease, in particular to the impairment of microcirculatory processes, initiation of free radical oxidation and reactive inflammatory process in the liver [17]. 
An additional blood loss model contributed to significantly greater impairments. The parameter was substantially decreased in the groups of LR-rats at all observation periods whereas in the groups of HR-rats after 3 days of the experiment, which indicates a stronger influence of pathogenic factors of acute blood loss in LR-rats on the functional state of the liver. An additional confirmation of the analysis made above was a greater degree of decrease in the studied parameter in the experimental groups of LR-rats. Consequently, an impairment of bile excretion function under conditions of an additional blood loss model, which causes the development of hemic hypoxia, evidences the hypoxia as one of the leading pathogenic factors contributing to the progression of hepatic dysfunction, which is consistently higher in the LR-rats. The above conditions lead to the exacerbation of lipid peroxidation, which results in the damage of endoplasmic reticulum of hepatocytes causing an impaired synthesis as well excretion of bile constituents at biliary pole of hepatocytes [3].

The medication Thiocetam was used for the correction of identified abnormalities. The first active substance of the medication called Piracetam stimulates the activity of antioxidant enzymes, stabilizes cell membranes, initiates the alternative metabolic pathways in the presence of hypoxia, and improves microcirculation [4]. The Thiotriazoline, being the second active substance, also exhibits antioxidant properties, and despite the enhancing the antioxidant enzymatic activity, acts as a scavenger of free radicals, as well as inhibits the generation of reactive oxygen species in mitochondria and contributes to the reparative liver regeneration. [11]. Consequently, the Thiocetam can influence the key mechanisms involved in abnormalities that we have identified in the background of trauma models.

The obtained results evidenced that the 7-day administration of the Thiocetam led to considerable decrease in abnormal bile excretion rate in the experimental groups of HR- and LR-rats compared to the animals without corrective medication. Therefore, Thiocetam, can, definitely, neutralize the negative effect of cranioskeletal trauma and its complication by acute blood loss. Probably, it is related to the stabilization of endoplasmic reticulum membranes associated with the synthesis of bile constituents and bile excretion at biliary pole of hepatocytes. A similar therapeutic effect on the bile excretion function of the liver has been confirmed by other authors [18]. The analysis of deviation degree of the studied parameter in the animals administered Thiocetam in relation to the animals without correction evidenced better efficacy of the medication in the experimental group consisted of LR-rats compared to the group of HR-rats especially under the conditions of additional acute blood loss model. Consequently, Thiocetam is able to compensate less-developed defense mechanisms of LRrats compared to the HR-rats, which should be taken into consideration in real-life clinical 
practice settings in the comprehensive treatment of the injured with cranioskeletal trauma complicated by blood loss considering the possibility to determine their resistance to hypoxia.

\section{Conclusions:}

1. The rate of bile excretion, being a basic indicator of the functional state of the liver, is significantly higher in the intact LR-rats as compared to the corresponding value of the intact HR-rats.

2. A cranioskeletal trauma leads to a considerable decrease in the bile excretion rate in the experimental groups of HR-and LR-rats relative to the control groups. However, the degree of decrease in the studied parameter of the LR-rats is considerably higher after 7 days of the posttraumatic period.

3. An additional blood loss model in the background of combined craniocerebral and femur trauma causes a significantly greater abnormal bile excretion rate in the experimental groups consisted of LR-rats compared to the experimental groups of HR-rats

The administration of Thiocetam is accompanied by a pronounced positive effect on the rate of bile excretion in the experimental groups of HR-and LR-rats, but the degree of increase in the studied parameter is considerably greater in the experimental group of LR-rats.

Perspectives of further research. The future research should be aimed at studying the dynamics of major bile components in response to cranioskeletal trauma, complicated by acute blood loss, in order to clarify the pattern of hepatic functional impairment in the HRand LR-rats.

\section{References:}

1. Borys R.M., Hozhenko A.I., Hudyma A.A. (2013) Dynamika pokaznykiv peroksydnoho okysnennia lipidiv u period rannikh i piznikh proiaviv travmatychnoi khvoroby za umov eksperymentalnoi kranioskeletnoi travmy ta yii korektsii klitynnoiu terapiieiu [The dynamics of indicators of lipid peroxidation in the period of early and late manifestations of traumatic disease in the presence of cranioskeletal trauma and its correction by cell therapy]. Klinichna ta eksperymentalna patolohiia - Clinical \& experimental pathology, vol. XII, no. 2 (44), pp. 31-34. [in Ukrainian].

2. Bayburina G.A., Nurgaleeva E.A., Bashkatov S.A., Shibkova D.Z. (2015) Vzaimozavisimost' pokazateley svobodnoradikal'nogo okisleniya v pecheni i krovi u krys s raznoy ustoychivost'yu k gipoksii posle perenesennoy anoksii [Association of blood and liver free radical oxidation indicators in rats with different resistance to hypoxia after survived 
anoxia]. Kazanskij medicinskij zhurnal- Kazan Medical Journal. vol. 96, no. 5, pp. 798-802. [in Russian].

3. Volotovska N. V., Hudyma A. A. (2011) Rol hemichnoi hipoksii v patohenezi porushen zhovchoutvoriuvalnoi i zhovchovydilnoi funktsii pechinky a tli skeletnoi travmy $\mathrm{v}$ rannomu posttravmatychnomu periodi. [The role of hemic hypoxia in the pathogenesis of impairments in the bile-forming and bile excretion functions of the liver in the early posttraumatic period]. Zdobutky klinichnoi $i$ eksperymentalnoi medytsyny - Achievements of Clinical and Experimental Medicine, 2(15). 31-33. [in Ukrainian].

4. Vostrikov V.V. Mesto piratsetama v sovremennoy prakticheskoy meditsine. [Place of piracetam in the modern practice of medicine]. Obzory po klinicheskoj farmakologi $i$ lekarstvennoj terapii - Reviews on Clinical Pharmacology and Drug Therapy. vol. 15, no. 1, pp. 15-25. [in Russian].

5. Huriev S. O., Fil A. Yu., Tanasiienko O. M. (2015) Analiz bezposeredikh prychyn smerti u postrazhdalykh iz politravmoiu ta poshkodzhenniam skeleta. [Analysis of the immediate causes of death of the injured affected by polytrauma and skeletal damage]. Travma. vol.16, no. 4, pp. 7-10. [in Ukrainian].

6. Zaiets T. A. (2014) Stan zhovchovydilnoi funktsii pechinky za umov kranioskeletnoi travmy, uskladnenoi krovovtratoiu [State of the biliary excretion liver function in the presence of cranioskeletal injury with blood loss complication]. Medychna khimiia. vol.16, no.1 (58), pp. 69-72. [in Ukrainian].

7. Kozak D. V., Datsko T. V. (2013) Dynamika strukturnykh zmin tkanyny pechinky u periody rannikh i piznikh proiaviv eksperymentalnoi travmatychnoi khvoroby. [The dynamics of structural changes of liver tissue in the periods of early and late manifestations of experimental traumatic disease]. Ukrainskyi zhurnal ekstremalnoi medytsyny imeni H.O. Mozhaieva. vol.14, no.4, pp. 85-90. [in Ukrainian].

8. Kozak D. V. (2012) Dynamika pokaznykiv tsytolizu v umovakh politravmy.[The dynamics of cytolysis markers under conditions of multiple trauma]. Shpytalna khirurhiia - Hospital Surgery. no. 2 (58), pp.50-52. [in Ukrainian].

9. Levchuk R. D. (2015) Rol porushennia vsmoktuvalnoi funktsii tonkoi kyshky v patohenezi rannoho periodu skeletnoi, cherepno-mozkovoi ta poiednanoi travm.[ Role abuse function of absorption of the small intestine in the pathogenesis of the early period of skeletal, craniocerebral and combined cranio sceletal injuries]. Shpytalna khirurhiia. Zhurnal imeni L. Ya. Kovalchuka - Hospital Surgery. Journal named by L.Ya. Kovalchuk. no.3, pp. 90-93. [in Ukrainian]. 
10. Merliev D. I., Hudyma A. A. (2015) Dynamika funktsionalnoho stanu nyrok v umovakh skeletnoi, cherepno-mozkovoi ta poiednanoi travmy u period rannikh proiaviv travmatychnoi khvoroby [The dynamics of functional state of the kidneys under conditions of skeletal, craniocerebral and combined trauma in the period of early manifestations of the traumatic disease]. Visnyk naukovykh doslidzhen - Bulletin of Scientific Research. no.2, pp. 90-93. [in Ukrainian].

11. Belenichev I. F., Vizir V. A., Mamchur V. I., Kurjata A. V. (2019) Mesto tiotriazolina $\mathrm{v}$ galeree sovremennyh metabolitotropnyh lekarstvennyh sredstv [Place of tiotriazoline in the gallery of modern metabolitotropic medicines]. Zaporozhskij medicinskij zhurnal - Zaporozhye medical journal. vol.21, no.1, pp. 118-128. [in Russian].

12. Mykhailiuk I. A., Hudyma A. A. (2015) Metabolichni porushennia v pechintsi $\mathrm{v}$ piznii period kranioskeletnoi travmy ta yikh korektsiia tiotsetamom [Metabolic disorders in liver in late period of cranial-skeletal trauma and their correction by Thiocetam]. Medical and Clinical Chemistry - Medychna i klinichna khimiia. vol.17, no.2, pp. 56-58. [in Ukrainian].

13. Mykhailiuk I. A., Hudyma A. A., Mykhailiuk V. M. (2015) Dynamika pokaznykiv tsytolizu v umovakh rannoho periodu travmatychnoi khvoroby pislia skeletnoi, cherepno-mozkovoi travmy ta yikh poiednannia [The dynamics of cytolysis markers in the early period of traumatic disease following a skeletal trauma, craniocerebral injury and their combination]. Visnyk naukovykh doslidzhen - Bulletin of Scientific Research. no.1, pp. 120122. [in Ukrainian].

14. Saturska H. S., Bondarenko Yu. I. (2014) Osoblyvosti metabolizmu spoluchnoi tkanyny pry eksperymentalnomu dyfuznomu ishemichno-nekrotychnomu kardiosklerozi u shchuriv iz riznoiu stiikistiu do hipoksii [Features of the connective tissue metabolism in experimental diffuse ischemic necrotic cardiosclerosis in rats with different resistance to hypoxia]. Visnyk VNMU. vol.18, no.2, pp. 425-429. [in Ukrainian].

15. Fil A. Yu.(2014) Khirurhichna kontseptsiia likuvannia postrazhdalykh iz politravmoiu u hostromu periodi [Surgical concept of treatment of patients with multiple trauma in acute period]. Travma. vol.15, no.5, pp.20-23. [in Ukrainian].

16. I. I. Horban, A. A. Hudyma, R. V. Maksymiv, I. V. Antonyshyn.(2020) Influence of two-hour tourniquets ischemia of limb and acute blood loss on systemic disorders of the body in the reperfusion period (experimental study). Wiadomości Lekarskie. vol. LXXIII, no.7, pp. 1330-1333. 
17. Kozak D. V. (2013) Lipid peroxidation, antioxidant defence, endogenous intoxication and cytolysis variations in early and late manifestations of traumatic disease. Journal of Health Sciences. vol. 3, no 4. pp. 108-117.

18. Mykhaylyuk I. A., Hudyma A. A. (2015) Disorders of liver functional state in late period of cranialskeletal trauma and their correction by thiocetam. Visnyk morskoi medytsyny. no.4, pp. 125-129. 